\title{
ERBB2 Gene
}

National Cancer Institute

\section{Source}

National Cancer Institute. ERBB2 Gene. NCI Thesaurus. Code C17756.

This gene plays a role in cellular proliferation and is involved in the oncogenic process

through amplification and/or overexpression in several cancers. 